\title{
The Relationship Between Educational Factors and Early Detection Behavior Cervical Ca in Fertile Age Women
}

\author{
Lilik Darwati*, Khusnul Nikmah \\ Lamongan Islamic University, Indonesia \\ *lilikdw08@gmail.com
}

\begin{abstract}
$\mathrm{Ca}$ cervix $\mathrm{s}$ is the most common cancer in women. Therefore, prevention efforts are needed as early as possible with early detection of cervical cervix. The aim of the study was to determine the effect of educational factors on the behavior of early detection of cervical caesarean at WUS in the UPT area of the subdistrict health center, kembangbahu, Lamongan Regency. The research design was analytic observational with cross sectional design. The population was all WUS with a sample of 369 respondents who were taken by using purposive random sampling technique. Education independent variable using a questionnaire and the dependent variable early detection behavior using observation. Data were analyzed using logistic regression test.

From the results of the study, it is known that almost half of the respondents in the implementation of cervical caesarean education, including less, namely 130 respondents and most of the respondents carried out early detection of cervical caverns with Pap smear, as many as 272 respondents out of a total of 369 respondents. There is a relationship between educational factors and the behavior of early detection of cervical caesarean at WUS p value $0.000<0.05$. Education is necessary in order untu $\mathrm{k}$ make someone knows $\mathrm{d}$ an encouraging someone to carry out early detection of ca cervix. There is a relationship between educational factors on the behavior of early detection of cervical cancer in women of childbearing age because the realization of behavior requires a variety of factors as a predisposition for the realization of behavior.

It was concluded that the educational actor was the dominant factor on the behavior of early detection of cervical cancer in women of childbearing age. It is suggested that the research site should increase the education regarding early detection of cervical caesarean at WUS.
\end{abstract}

Keywords: Educational Factor, Early Detection Behavior of Cervical Ca, Women 


\section{STRADA Jurnal Ilmiah Kesehatan}

DOI: $10.30994 /$ sjik.v9i2.491

ISSN: 2252-3847 (print); 2614-350X (online)

Vol.9 No.2 November 2020 Page.1481-1488

\section{BACKGROUND}

Cervical cervical cancer is the most common cancer in women in the world. Deaths from cervical $\mathrm{Ca}$ are projected to increase by nearly $25 \%$ over the next 10 years. More than 270,000 female deaths due to cervical cancer each year in developing countries than in manju countries (WHO, 2013). As the name implies, cervical cervical cancer is a cancer that occurs in the uterine cervix, an area in the female reproductive organ which is the entrance to the uterus which is located between the uterus ( uterus ) and the intercourse hole ( vagina ) . The term "cancer" itself is already very scary. Therefore, it is expected that the incidence rate of this cancer can be reduced as low as possible (Anurogo, 2009).

In Indonesia, based on data from the 2013 Basic Health Research, the incidence of cervical caesarean in women was 522,354 patients (Trihono, 2013). In East Java, based on data from the 2013 Basic Health Research, the incidence of cervical caesarean in women was $1.6 / 100 \%$ o (Trihono, 2013).

Table 1.2 Scope of Examination of Early Detection Ca cervix In UPT Puskesmas region kembangbahu

\begin{tabular}{clcccc}
\hline & \multirow{3}{*}{ No. } & Month & \multicolumn{5}{c}{ Early Detection of Cervical Ca } \\
\cline { 3 - 6 } & & IVA & PAP smear & IVA & PAP smear \\
\cline { 3 - 6 } & & 6 & - & 3 & - \\
\hline 1 & January & 7 & - & 3 & - \\
2 & February & 2019 & 3 & - \\
3 & March & 2 & - & - & 105 \\
4 & April & - & 108 & & \\
5 & May & 10 & - & & \\
6 & June & 1 & - & & \\
7 & July & - & 38 & & \\
8 & August & - & - & & \\
9 & September & - & - & & \\
10 & October & - & - & & \\
11 & November & - & - & \\
12 & December & - & - &
\end{tabular}

Source : Register of outpatient Puskesmas Kembangbahu

The high incidence rate of cervical $\mathrm{Ca}$ can be caused by various factors. The cause of this cancer is the Human papilloma virus ( $H P V)$, which is a type of virus that attacks humans (Kompas, 2008). According to the National Institute of Environmental Health Science in Research Triangle Park, North Carolina, the compound Bisphenol A, which is a chemical substance used to make hard plastic containers, such as water jugs and for lining soup cans) can cause breast cancer, ovarian cancer, uterine cancer, endometriosis, and fertility problems. In pregnant women, this chemical substance can be passed on to the fetus (Roman, 2013). Cervical Ca occurs because of abnormal (abnormal) cell growth in the cervix. But before these cells become cancer cells, there are several changes that are experienced by these cells. These cell changes usually take up to many years before the cells turn into cancer cells.

Risk factors for cervical cancer include women having had sexual intercourse, smoking women, having multiple sexual partners, starting sexual activity at a very young age (Riono, 2009). Risk factors that can increase your chances of cervical cancer include age when you first had sex less than 20 years, having multiple partners, having had 


\section{STRADA Jurnal Ilmiah Kesehatan}

DOI: $10.30994 /$ sjik.v9i2.491

ISSN: 2252-3847 (print); 2614-350X (online)

Vol.9 No.2 November 2020 Page.1481-1488

sexually transmitted infections, mother or sister having cervical cancer, previous abnormal pap test results and smoking. (Ministry of Health, 2015). Sri Syatriani's (2011) research results show that risk factors for cervical cancer can also be triggered by the use of low quality sanitary napkins ( $\mathrm{OR}=2,320)$, use of soap $\mathrm{pH}>4(\mathrm{OR}=2,360)$, socioeconomic status $(\mathrm{OR}=4.087)$ and male partners who do not were circumcised $(\mathrm{OR}=2,092)$. The impact that arises in the early stages is the appearance of foul-smelling, pink or brownish vaginal discharge, bleeding, abnormal menstruation and pain during sexual intercourse (Anurogo, 2009).

Given the impacts that arise, efforts should be made to avoid cervical caesarean . The first is that if you have had sexual intercourse, you must do early detection of cervical $C a$ by means of a regular pap smear test every two years until the age of 70 years. The second thing is to report abnormal symptoms such as bleeding, especially after coitus (intercourse). The third thing is not smoking (Riono, 2009). Another method besides the pap smear is by visual inspection with acetic acid. Currently, cervical cancer can also be prevented by giving the HPV vaccine. This step can provide protection against several types of HPV that can cause cervical caesarean and genital warts (Kompas, 2008).

The problem is still a lot of $\mathrm{W}$ anita Age fertile that do not implement early detection of Ca cervix. Many factors cause the lack of implementation of this early detection. A study of the behavioral aspect according to Green (Notoatmodjo, 2010) that someone is willing to do something, for example, early detection of cervical cancer if he knows the purpose and benefits. After knowing it will determine the attitude, namely agreeing or disagreeing with the program. After that it also depends on perceptions, values, beliefs. Likewise, it will depend on enabling factors such as the availability of affordable health facilities to carry out early detection, social support and so on. Maslow in the theory of motivation says that people will be motivated to do an action based on their need, besides their desire or interest or motivation. Encouragement or strong motivation must be instilled in the sufferer through various approaches. It is hoped that soon there will be interest in carrying out early detection of cervical ca.

Based on the above researchers intend to do research to formulate in the title: " Analysis of Educational Factors and Motivation to Behavior of Early Detection of $\mathrm{Ca}$ cervix in woman of fertile age in the region of UPT Puskesmas Kembangbahu Lamongan".

\section{METHODS}

The research design used was observational analysis, namely research by observing the research subjects (Notoatmodjo, 2012). With a cross-sectional approach, a research conducted to determine the relationship between variables according to requests without intervention from researchers, where data collection or collection on each research subject is only observed once (Sugiyono, 2010).

The sampling technique chosen by the researchers in this study was proportional cluster random sampling (sampling based on random cluster proportions). The cluster in question is 18 villages in the UPT Puskesmas Kembangbahu area, Lamongan Regency.

In this study, the population was all women of childbearing age who were married at the UPT Puskesmas Kembangbahu, Lamongan Regency, as many as 9,479 WUS who were married. In this study, the samples of this study were some women of childbearing age who were married as many as 369 respondents.

Analytical techniques for assessing the validity of the instrument using the Pearson product moment correlation calculation with a significance level of $\alpha=0.05$ 


\section{STRADA Jurnal Ilmiah Kesehatan}

DOI: $10.30994 /$ sjik.v9i2.491

ISSN: 2252-3847 (print); 2614-350X (online)

Vol.9 No.2 November 2020 Page.1481-1488

\section{RESULTS}

The Effect of Educational Factors on Early Detection Behavior of Cervical Ca.

Table 4:38 Logistic Regression Test Results The Effect of Educational Factors on Early Detection Behavior of Cervical Ca 2 April to 2 May 2020

\begin{tabular}{lc}
\hline \multicolumn{1}{c}{ Variable } & $p$ value \\
\hline Education - Early detection behavior of cervical ca. & 0,000 \\
$\mathrm{~N}=369$ & \\
$\alpha=0.05$ & \\
\hline
\end{tabular}

Based on table 4.38, it is known that there is an effect of educational factors on the behavior of early detection of cervical cancer in women of childbearing age at Puskesmas Kembangbahu, Lamongan Regency ( $p$ value $0.000<0.05$, so Ho is rejected).

Based on the results of logistic regression didapa VING equation There are relationship factors on the behavior of early detection education ca cervix in women aged road towards Puskesmas Kembangbahu Lamongan of 4.430 with $p$ value $0.000<0.05$ then Ho is rejected .

\section{DISCUSSION}

Based on table 4.7, it is known that almost half of the respondents in the implementation of cervical caesarean education for women of fertile age are in the less category, namely 130 respondents $(35.2 \%)$ of the total 369 respondents.

The results of this study are in line with previous research by Sri Wahyuni (2011) which states that the most dominant factor influencing cervical cancer early detection behavior is the wish and drive method educational intervention with a value of $p=0.010$ and OR 3.050. This is because education is a determining factor because it is health education given to respondents by paying attention to the client's background and needs, this education provides a form of learning with various stimuli including lectures using LCDs, CD playback, distribution of booklets, peer discussions, demonstrations of Pap smear examinations and counseling. by involving family as supporters. Education is carried out to make the respondent's internal and external factors effective because these factors can influence the behavior of early detection of cervical cancer. As research conducted by Ackerson in 2007 in America, in his research which aims to determine the factors that influence women in early detection of cancer, it was found that the behavior of early detection of cervical cancer is influenced by intrinsic and extrinsic factors including age, education, economic status and knowledge.

According to Notoatmodjo ( 2010), education is a learning process from not knowing the value of health to knowing and from being unable to cope with one's own health to becoming independent. In this case the main role of education is to increase knowledge. Knowledge is needed in order to change behavior as described in the KAP ( knowledgeattitude-practice ) concept, where knowledge underlies attitudes and attitudes underlie the formation of behavior .

Nearly half of the respondents implementing cervical caesarean education in women of fertile age were in the poor category. This is due to the implementation of edu ca cervix is required infrastructures including the $\mathrm{z}$ Program is carried out for this activity. The means and infrastructure in question are the need for learning media such as books, magazines, newspapers or the internet and even outreach activities by health workers. For this tool, not everyone has it. Including now that is already popular is the internet, not necessarily 


\section{STRADA Jurnal Ilmiah Kesehatan}

DOI: $10.30994 /$ sjik.v9i2.491

ISSN: 2252-3847 (print); 2614-350X (online)

Vol.9 No.2 November 2020 Page.1481-1488

everyone uses an Android cellphone that can be used for internet access to read cervical cancer which often occurs in women of fertile age.

Besides the above conditions education program ca cervix in women of fertile age are included is still in the low category can also be caused by other factors related to the characteristics of respondents as a factor of age, background education, employment, status gravida, information and resources. Judging from the age factor, based on the results of the analysis, it was found that the most respondents were $>35$ years old with education in the good category. This is due to the older a person, the accumulation of education is certainly more than those aged her younger. This possibility can occur because education can come from various sources, whether from books, magazines, newspapers, the internet, health workers, friends or others.

Another factor that causes the lack of education about cervical cancer is related to the educational background of the respondent. Based on the results of the analysis, it is known that most respondents have primary education with cervical caesarean education in the low category and high school with good category. This is because with low education, people are generally reluctant to learn something, including being reluctant to read as a source of education. On the other hand, the higher the level of education, the higher the desire to learn and study in general. Therefore, with high school education, the education is among the highest compared to the SD education group .

Another factor that also affects the lack of implementation of cervical cancer education is the work background of the respondents. Based on the results of the analysis, it was found that the most respondents were farmers with cervical cancer education, including the low category. This is due to his profession as a farmer, so he rarely needs education about cervical cancer. People in this profession are generally more focused on agricultural problems. Information outside of agricultural issues in general also attracted less attention. Therefore, in the end, this group of farmers receives the least amount of information about cervical cancer.

Besides the above factors are also related to the gravida status of the respondents. Based on the results of the analysis, it was found that the most respondents were multigravidas with education in the poor category. This is because, in general, people are still less concerned with preventive measures regarding disease. Including still less concerned about cervical ca. problems. Therefore, even though it is classified as multigravida, it is still lacking in education about cervical caesarean .

The last factor that influences is information. Based on the results of the analysis, it was found that the most respondents had received information about early detection of cervical caesarean with education in the poor category. This is due to the fact that the category of having received information about early detection of cervical caesarean even though only once was still assessed as having. Therefore, even though it includes getting information about early detection of cervical cancer, education about cervical caesarean is still considered lacking. The reason is that respondents seem reluctant to seek information on their own and are passive or rely solely on information from health workers. Based on the results of the analysis, it was found that the most respondents got information about early detection of cervical caesarean from health workers with education in the poor category. 


\section{STRADA Jurnal Ilmiah Kesehatan}

DOI: $10.30994 /$ sjik.v9i2.491

ISSN: 2252-3847 (print); 2614-350X (online)

Vol.9 No.2 November 2020 Page.1481-1488

\section{CONCLUSION}

Nearly half of the respondents at the Kembangbahu Public Health Center in Lamongan Regency for the implementation of cervical caesarean education for women of fertile age are in the poor category .

Most of the respondents at the Kembangbahu Public Health Center in Lamongan Regency, including carrying out early detection of cervical caesarean with a pap smear.

There is a relationship between educational factors and the behavior of early detection of cervical cancer in women of childbearing age at the Kembangbahu Public Health Center, Lamongan Regency

\section{REFERENCES}

Abdul Muhith, Nasir, A \& Ideputri, ME 2011. Handbook of Health Research Methodology, Nuha Medika: Jogjakarta

Ahmad Abu. 2007. Social psychology . jakarta: PT. Rineka Cipta

Anurogo. 2009. What is the difference between cervical cancer and cervical cancer ? http://netsains.com/2009/10/apa-beda-kanker-leher-rahim-dan-kanker rahim / . Lamongan (accessed April 19,2017)

Azwar.s 2008. Human Attitudes Theory and Measurement . Yogyakarta: Liberty

MOH RI. 2013. Reference Book for Cervical Cancer and Breast Cancer Prevention. Jakarta: Directorate of Non-Communicable Disease Control, Directorate General of PP\&PL, Ministry of Health RI . Lamongan (accessed April 19,2017)

East Java Health Office, 2010. Health Profile of East Java Province . www.dinkesjatim . Go. Id

Lamongan Health Office. 2017. Report on the implementation of iva test in Lamongan district: Dinkes Lamongan.

Dyah Astrid, 2016. An overview of the visual inspection of acetate as an early detection of cervical precancerous lesions in indirect female sex workers at HotSport X, Kecamatan Marpoyan Peace, Pekanbaru. Riau Medical Faculty. Lamongan (accessed April 19,2017)

Eva sulistiowati. 2012. Knowledge of risk factors, behavior and early detection of cervical cancer by visual inspection of acetic acid (iva) in women in the subdistrict of Central Bogor, Bogor City. USU's School of Public Health. Lamongan (accessed April 19,2017)

Ginting, A. 2008. The Practical Essence of Learning \& Learning . Bandung: Humanities

Husain, U. 2008. Research methods for theses and theses . Jakarta: PT Grafindo Perdana

Indah Kurniawati. 2015. The influence of knowledge, motivation and husband's support on the behavior of iva examination in a group of women of childbearing age at the Kedungrejo Health Center. Surakarta Sebelas Maret University Postgraduate Program. Lamongan (accessed April 19,2017)

Janah, WN 2013. The level of knowledge of the Dmpa injection family planning acceptor (depo medroxy progesteroneAsetat) about the timeliness of Kb Injections at BPM Yuliana Banaran Sragen. Http://igilib. Stikeskusumahusada. Air conditioning. Id. Lamongan (accessed April 19,2017)

RI Ministry of Health. 2015. The Situation of Cancer",

http://www.depkes.go.id/article/view/15021800011/situasipenyakitkanker.html. Lamongan (accessed April 19,2017) 


\section{STRADA Jurnal Ilmiah Kesehatan}

DOI: $10.30994 /$ sjik.v9i2.491

ISSN: 2252-3847 (print); 2614-350X (online)

Vol.9 No.2 November 2020 Page.1481-1488

Compass. 2008. Time to Prevent Cervical Cancer . http://id.shvoong.com / medicine-andhealth / 1768033-it's-time-to-prevent-cervical-cancer /. Lamongan (accessed April 19,2017)

Kunthi isti M. 2016. The relationship between socio-economic factors and the delay in diagnosis of cervical cervical cancer patients at Semarang City Hospital in 2016. Semarang State University. Lamongan (accessed April 19,2017)

Manuaba, Ida Bagus Gde. 2009. Understanding research on women's reproductive health . Jakarta: Arcan. Page: 206

Martini, NK, 2012. The Relationship between Characteristics, Knowledge, and Attitudes of Women in Fertile Age Couples with Pap Smear Examination Measures at Puskesmas Sukawati II , Thesis, Udayana University. Lamongan (accessed April 19,2017)

Mojgan Karimi, 2009. Cervical Cancer And HPV Vaccines In Developing Countries In Asian Pacific. journal of cancer prevention. Lamongan (accessed April 19,2017)

Mubarak. 2009. Public health sciences: Theory and Applications . Jakarta: Publisher Salemba Medika

Myriam leyva Dkk, 2006. Attitudes Towards Cervical Cancer Screening: A Study of Beliefs Among Women In Mexico Year 2006. Thr University of Texas of public health. Lamongan (accessed April 19,2017)

Notoatmodjo, S. 2010. Health Education and Science Behavior . Jakarta: Rineka Cipta.

Notoatmodjo, S. 2010. Health Promotion Theory and Application, Jakarta: Rineka Ilmu.

Notoatmodjo, S. 2012 . Research methodology in Health . Jakarta: Rineka Cipta.

Notoatmodjo, S. 2014 . Behavioral Health Sciences . Jakarta: Rineka Cipta.

Nursalam. 2014. Concept and Application of Nursing Research Methodology . Jakarta: Salemba Medika.

Ocviyanti . 2010. Various Techniques for Early Detection of Cervical and Breast Cancer. Jakarta: Department of Obstetrics and Gynecology, FKUI

Ombech Elizabeth A. 2012. Awareness Of Cervical Cancer Risk Factors And Practice Of Pap Smear Testing Among Female Primary School Teachers In Kasarani Division, in Nairobi Kenya. African journal of health sciences. Lamongan (accessed April 19,2017)

PKM Kembangbahu. 2017. Kia's outpatient register book. PKM Kembangbahu

Roura E, 2016. Influence of Hormonal Factors on the Risk of Developing Cervical Cancer and Pre-Cancer. https://doi.org/10.1371/journal.pone.0151427

Riduwan and Sunarto. 2007. Introduction to Statistics for Educational, Social, Economic, Communication, and Business Research . Bandung: Alfabeta. Page: 72

Riono. 2009. Cervical Cancer . http://dokter.indo.net.id/serviks.html . Lamongan (accessed April 19,2017)

Roman. 2013. Inner Healing At Home ( Strategy "Ward off" Sources of Disease and Cancer Triggers in Your Home ). Jakarta: Publisher PT Elex Media Komputindo Gramedia Group. Lamongan (accessed April 19,2017)

Rosmala Dkk, 2012. Changes in knowledge and attitudes of women who have a partner on pap smear examination before and after. Provided counseling on Early detection of cervical cancer by pap smear examination in glugur Drata 1 district, East Medan district . USU's School of Public Health. Lamongan (accessed April 19,2017)

Soegiri Hospital. 2017. The Obstetric Poly Outpatient Register Book . Lamongan : Soegiri Hospital. 


\section{STRADA Jurnal Ilmiah Kesehatan}

DOI: $10.30994 /$ sjik.v9i2.491

ISSN: 2252-3847 (print); 2614-350X (online)

Vol.9 No.2 November 2020 Page.1481-1488

Saifudin, 2010. Practical guidebook for contraceptive services . Jakarta. Bina Pustaka Sarwono Prawirohardjo Foundation.

Sastroasmoro \& Ismael. 2010. Basics of Clinical Research Methodology . Jakarta: Sagung Seto

Sedarmayanti and Hidayat. 2012. Research Methods . Bandung: Mandar Maju.

Sheikh Haroon, 2012. Role Of Pap Smear In Early Diagnosis Of Cervical Cancer- A Case Study Of Women In Saudi Arabia Year 2012 . http://www.lifesciencesite.com . Lamongan (accessed April 19,2017)

Sinta Oktavyany. 2015. The relationship between the level of knowledge about cervical cancer and attitudes towards the examination of pap smears in pus at the Semanu Gunung Kidul Public Health Center. POLTEKES Permata Indonesia. Lamongan (accessed April 19,2017)

Sisca Nida Mayrita, 2012. The relationship between parity and the incidence of cervical cancer is found in Wisnuwardhana cancer, Surabaya. Wisnuwardana Cancer Foundation. Lamongan (accessed April 19,2017)

Sri Syatriani, 2011. Risk factors for cervical cancer in the government general hospital Dr.wahidin sudirohusodo Makassar, South Sulawesi. Stikes Makassar. Lamongan (accessed April 19,2017)

Sri Wahyuni. 2011. The educational effectiveness of the wish and drive method on the behavior of cervical cancer early detection in Ngampel sub-district, Kendal district, Central Java. Nursing Study Program, Faculty of Medicine, University of Indonesia. Lamongan (accessed April 19,2017)

Sudarso. 2007. Making Scientific Writing in the Health Sector . Surabaya: Duatujuh.

Sugiono, 2011. educational research methods (quantitative, qualitative and $R \& L$ approaches). Bandung Alfabeta.

Sugiyono. 2008 . Statistics For Research . Bandung: Alfabeta.

Sukmadinata, N. (2010). Educational Research Methods , PT Remaja Rosdakarya: Bandung.

Suliha, U. et al. 2012. Health Education in Nursing . Jakarta: EGC.

Trihono. 2013. Basic Health Research . Jakarta: Ministry of Health RI

Widyasari. 2010. Relationship Between Knowledge and Motivation of Women in Fertile Age Couples (PUS) in Conducting Pap Smear Examination in Mander Village, Tambakboyo District, Tuban Regency. DIII midwifery RSI Tuban.

World Health Organization. Human papillomavirus (HPV) and cervical cancer. Fact sheet. 2013 [cited 2013 Sep]; 380: [about 3 screens] Available from: http://www.who.int/mediacentre/factsheet/fs380/en/. Organization $2012 ; 90$ : 478-478A. Lamongan (accessed April 19,2017)

Yuli kusumawati. 2016. Knowledge, early detection and HPV vaccine as a preventive factor for cervical cancer in Sukoharjo district in 2016. Semarang State University. Lamongan (accessed April 19,2017)

Zainudin, 2009, Legal research methodology, Sinar Grafika, Jakarta. 